\title{
EMPOWERING COMMUNITIES THROUGH CREATION OF MURAL ART AS AESTHETIC SUPPORT IN 'KEDAI OMAH JLAMPRANG' PEKALONGAN
}

\author{
Hagung Kuntjara SW and M. Imam Tobroni \\ Bina Nusantara University, Indonesia. \\ hwijasa@binus.edu
}

\begin{abstract}
Krapyak Village - Pekalongan, is currently improving itself to become a tourist destination based on the carrying capacity of Geographical, Cultural, Human Resources owned, including; Slamaran Beach, Batik Industry with typical motifs of Jlamprang, Culinary specialties of Pekalongan, and community human resources who will be trained in their independence. Community Development Academic (CDA) - Binus University facilitates the transfer of knowledge from lecturers from various interdisciplinary disciplines to be applied directly to the community or community that requires capacity building in connection with the preparation to develop tourist destinations. Through a long collaboration and discussion between the campus and the government of Krapyak Pekalongan Urban Village, it was decided to build a culinary shop where joint learning could serve typical Pekalongan meals, outlets selling batik and handicraft products of SMEs, as well as a convenient spot for community gathering to build understanding of tourist area preparation. Through training programs on the physical building architecture of the shop, Interior Design settings and selection of equipment for chairs and souveneer creation training, mapping of tourist attractions, culinary training in making menus and cooking, Management of shop and financial management. Visual Communication Design plays a role in the creation of identity branding, starting from naming 'Kedai Omah Jlamprang' and its completeness and Mural Art to build a cozy atmosphere of a shop through the work of aesthetic elements that have meaning. All of these training programs involve discussions and practical workshops on product creation that involve lecturers and SME communities in the Krapyak - Pekalongan village, so that the objectives of the Fostering \& Empowering Society can occur. It is hoped that this process will build trust and desire to grow economic independence in the community.
\end{abstract}

\section{Keywords : Empowering Society, Workshop, Transfer Knowledge, Murat Art}

\section{INTRODUCTION}

Pekalongan is one of the cities in Central Java bordering the Java sea in the north, Batang regency in the east, and Pekalongan regency in the west and south. Pekalongan City consists of 4 districts, namely West, North and East Pekalongan. Pekalongan is located on the northern coast of Java (Pantura) which connects Jakarta Semarang - Surabaya.

Pekalongan is known as the 'city of batik', there can be found a Museum of Batik - Pekalongan with the most complete collection of batik cloth from the archipelago and especially Pekalongan batik. Batik Pekalongan has a long history due to Pekalongan's strategic geographical position making the trade lane of the last century crowded there. Batik Pekalongan has a unique and varied style according to its historical journey. Now Pekalongan City is a UNESCO creative city network in the category of crafts \& folk art in December 2014 and has a city branding 'Pekalongan World's city of Batik'.

Pekalongan's special food is Megono Rice \& Soto Tauto. Megono rice which is jackfruit slices mixed with coconut condiment sauce is often found and seems to be the daily food of the community. While Soto Tauto is often found along the Pekalongan Pantura lane, Soto Tauto shops are open 24 hours and as the saying goes 'It hasn't reached Pekalongan if you haven't enjoyed Soto Tauto'.

The city of Pekalongan is famous for its religious nuance because the majority of the population embraces Islam, there are a number of traditions in Pekalongan that are not found in other areas, for example: syawalan, 'Sedekah Bumi', and so on. Syawalan is a celebration of seven days after Eid and is now enlivened by a record-breaking giant lupis cake recorded by the Indonesian Record Museum (MURI) by the mayor of Pekalongan to then be distributed to the visitors. Since the completion of the construction of the Cipali - Semarang Highway (2019), practically most of the crossing vehicles or seasonal travelers when Lebaran no longer stops at Pekalongan City. The Pekalongan city government made a strategic plan so that people would take a short break from a long journey on the Toll Road to stop by the city of Pekalongan. Therefore according to the Pekalongan city development plan, several tourist destinations will be activated, including the Charm of Slamaran Beach, the Center for Batik shop, and other supporting facilities. It is hoped that with the new tourist attraction, the wheels of the people's economy can continue to spin and regional income increases. 
Through Community Development Academic (CDA) - Binus 2019 in collaboration with the Government of the City of Pekalongan, trying to build community capacity building around tourist destinations so that there is a 'tourist-aware community' that has an understanding and skill as a host of tourist destinations. The Binus CDA was attended by various groups of interdisciplinary lecturers who collaborated and formulated a common goal, building a Hub that was expected to be a center of community learning about the readiness of the 'Tourism Awareness Community'. It is hoped that starting from this point it will become a social catalyst beginning which will later become a major actor in public tourism services. The hub in the form of a shop is named 'Kedai Omah Jlamprang' a gathering place for officials, voluteers, communities, and the community to conduct "teachinglearning" as well as a place to relax enjoying the culinary and selling batik products and handicrafts of UKM. It is hoped that there will arise constructive ideas relevant to the realization of the new tourism tourism Pekalongan, and the readiness of the community as the main actors so that the economy is felt equally among the people involved.

\section{METHOD}

Binus CDA - Mural Art project team uses the 'Design Project - Participatory' model or method, as well as in a Team in a design or art production house. The division of team members shows the role and responsibility of each individual in carrying out the stages of the Mural Art project.

\begin{tabular}{|c|l|c|}
\multicolumn{2}{|c|}{ Allocation of roles that will be given responsibility of mural art } \\
\hline No & \multicolumn{1}{|c|}{ Division of Teams } & Indicator of Achievement \\
\hline 1 & Concept of Mural Art Design \& Presentation & CDA chairmen \& members \\
\hline 2 & Field Supervisor & CDA Team \& Volunteer \\
\hline 3 & Field execution & Karangtaruna of Krapyak village \\
\hline 4 & Supervisor Project, Finishing Touch \& QC & CDA chairmen \& members \\
\hline
\end{tabular}

Tabel 1. Roles \& Responsibilities of the Mural Art Project Team

The 'Participatory Design Project' brought all CDA Binus and Karangtaruna participants in Krapyak village to understand through mapping the potential that could be used as an inspiration for Mural Art, Analysis, Concepts and Ideas, choosing the right material for execution, and implementation in the field. Each stage of the process is carried out by briefing objectives \& goals, disscusion, design workshops, and implementation on site.

\section{RESULT \& DISCUSSION}

Mural Art is the art of drawing on a wall or a broad medium in a public area to be painted. Mural itself means 'Murus' or a wall in Latin. Wall paintings have been known to people since ancient times, found in the cave Leang-leang, Batimurung-Maros, Sulawesi. Ancient frescoes were also found in the famous Lascoux cave in Dordogne, France.

In the Middle Ages, churches hired great artists to paint the walls of the church with very famous religious decorations. But now Art Mural is not only intended to express themselves in the public space, but also is a media that requires public issues. Murals are also widely used to decorate the walls of cafes, offices to create an atmosphere and are artistic.

At Kedai Omah Jlamprang-Pekalongan, Mural Art is needed as a sign of a unique identity as well as an artistic decoration to decorate and create a comfortable atmosphere. Art Mural with large size will immediately seize the attention and build a Cozzy comfort atmosphere, visitors will be united and immersed in the situation built, even visitors can style by capturing a photo of himself in front of the Mural as a selfie or wefie if together.

The creation of Mural Art itself has stages of the process up to the process. This sequence of processes can be used as a benchmark so that all the established routes can be applied to the creation of commercial Mural Art on other occasions. By understanding the stages and tricks and tips in working on Mural Art, the participants involved will gain experience and knowledge in the creation of Mural Art.

Simply put, the creation of Art Mural can be explained in the following order;

1. Formulate the purpose of Mural Art, the benefits and what it is used for

2. Research processes, ideas or visual ideas and determine the type of technical coloring

3. Present to the buyer or wall owner about the concept of ideas, technical execution, and view image simulation if the mural has been applied to the wall area 
4. Determine the color scheme according to the agreed design agreement

5. Sketch the transfer of design drawings to the wall using the scalatic method transfer guide using image projection with the help of a projector,

or use a design transfer with digital print

6. Coloring with paint that has been purchased based on color guidelines or digital printing on a medium wide print area (fabric, vinyl, wood, etc.)

7. Finishing touch and cleaning the area after work

8. Submission of Mural Art works according to work timeline and agreement.

\section{a. Research Stages}

It was found that the Jlamprang Batik motif is a typical Pekalongan Batik originating from the Krapyak Village. Historically Krapyak is a coastal sea area that allows large ships to dock and flow through rivers connected to the Lodji river in the center of Pekalongan city. Batik merchants have existed and have been hereditary since the colonial era. Jlamprang motif itself in the form of rounded geometric shapes or repetitive boxes or flat motifs containing lung motifs with a lotus flower in the middle. It is believed that this motif was adopted from double ikat cloth or called patola brought by traders from Gujarad, India in the 18th century AD Brightly bright colors were the influence of the Chinese, Indians, and Arabs who traded across the continent at that time.

In another motif in the middle of Pekalongan, a bouquetan or motif of a flower arrangement is found. The Dutch Bouquete Batik motif that began more or less in 1840 and was pioneered by Caroline Josephine Van Franquemont and Catherina Carolina Van Oosterom who lived in Pekalongan. Buketan motifs are in great demand and are widely applied to batik, ceramic painting, and other handicrafts.

Pagi-sore or the morning - afternoon batik cloth, which is batik cloth divided by two motifs that meet diagonally in the middle of the fabric. The design of the placement of batik motifs like this existed in 1930 in Pekalongan. Pagi-sore batik designs were very popular during the Japanese colonial era because at that time due to the difficulty of life, for savings, batik made pagi-sore batik cloth. One batik cloth is made with two different motif designs. So if in the morning we use one side of the motif, then in the afternoon we can wear a different motif from the other side of the fabric, so that we seem to have 2 different fabrics even though only 1 sheet of cloth. The darker colors are usually worn on the outside for morning and afternoon, while the pastel colored batik is used at night events. The motives of the morning - afternoon are often found on Batik Djawa Hokokai in Pekalongan during the Japanese occupation (1942-1945) during World War II.

The Megono and soto tauto rice dishes are very popular in Pekalongan. At Kedai Omah Jlamprang, culinary folk are made a variety of new snacks that are suitable for the portion of the cafe. Megono rice becomes a megono roll omelette, also supplied with alang-alang shaved coconut as a typical drink of a tavern. All the work of Binus CDA friends' workshops with young women and women from PKK in Krapyak Pekalongan village. Culinary will also be a source of inspiration that will be raised on the mural image.

Community Insight

The Krapyak people want the village of Karpyak, which used to be famous with batik Jlamprang, can become popular again in the present, it is expected that the community's economy will be lifted by the participation of the community in the operation of tourist attractions as well as a new outlet for Pekalongan batik vendors and local culinary providers.

\section{b. Idea \& Stages Design}

The Mural Art Area is on one side of the Kedai Omah Jlamprang with an area of 6x1.5m, divided into 4 mural modules. The division of this module allows for 4 visual stages with different color shifts to adopt the principle of batik patterns pagi-sore. 


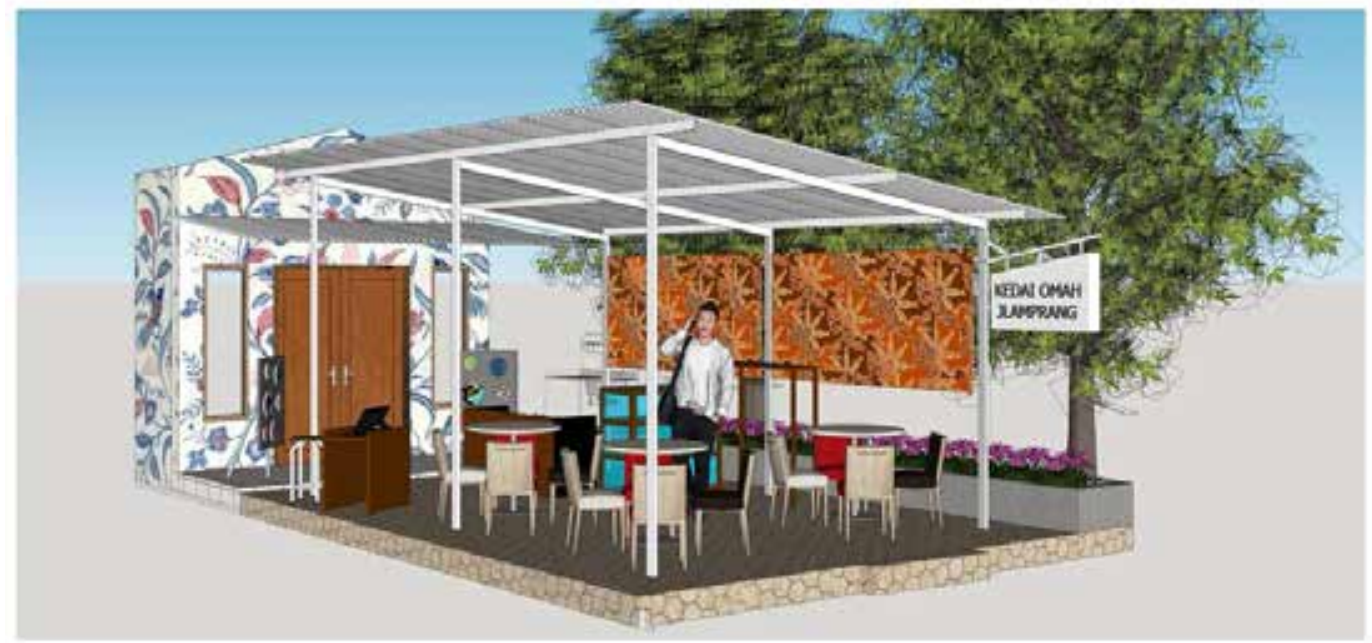

Figure 1. Space Area - Art Mural

(source : CDA Arsitektur Binus 2019)
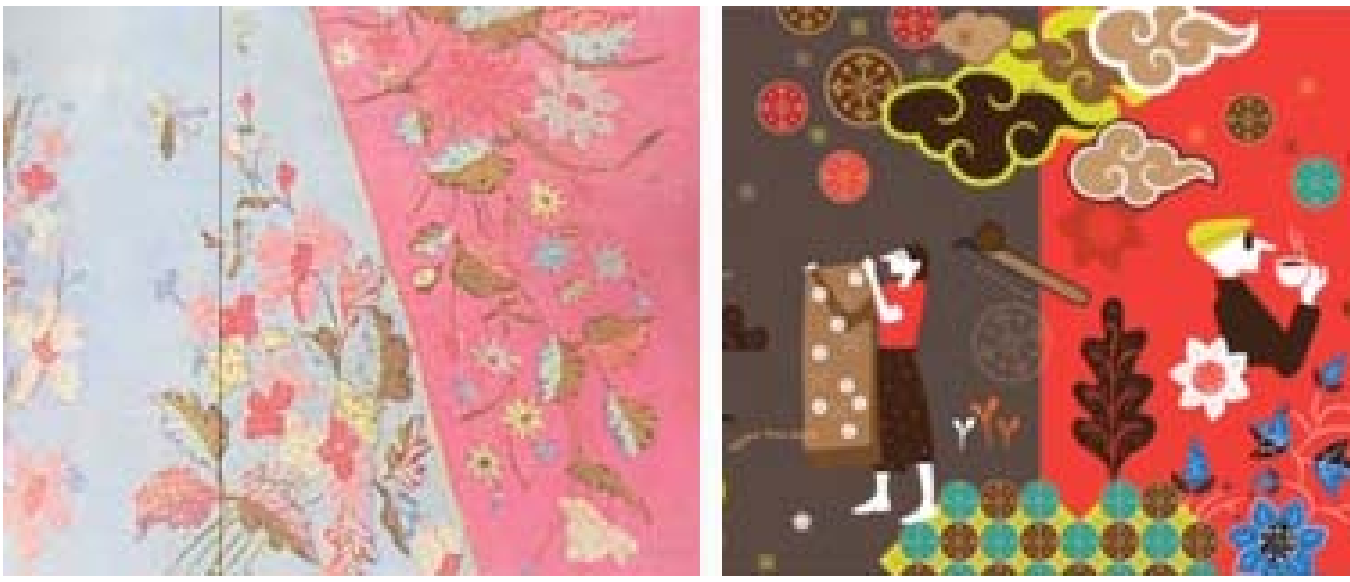

Figure 2. Adaptation to the merging of the Pagi-Sore Batik Pattern on Art Mural (source : Author)

The idea of mural art at Kedai Omah Jlamprang must illustrate the potential and identity of Pekalongan as the World's City of Batik, so that all 3 potential batik patterns of research results are the mural art frame and the depiction of the batik production process and the convenience of the shop convenience being the main idea. In the mural art frame, the motif of Jlamprang is always raised as the dominant motif.

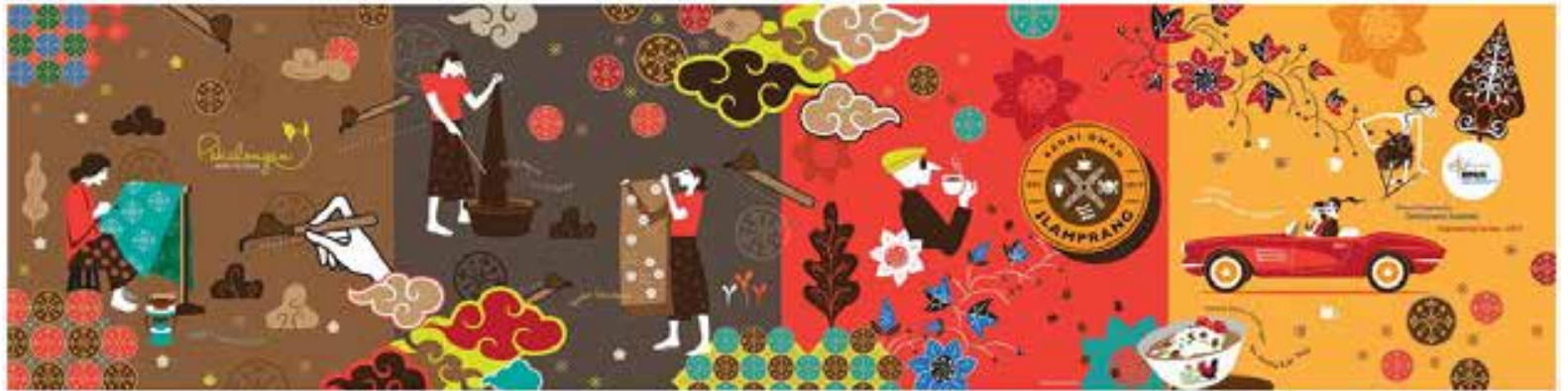

Figure 3. The Mural Art design was applied to the Jlamprang frame, as well as the Buketan Motif Coloring adapts to the Batik Pattern Pagi-sore.

(source : Author)

2 rounds tell the story of the process of making batik and the next 2 rounds tell the story of a tavern with a buketan flower motif into a visualization of the leasure. The Pekalongan World's City of Batik logo accompanied the first 2 rounds and the Kedai Omah Jlamprang logo in the layout represented the atmosphere of the next 2 rounds. 
This idea was discussed and obtained input and agreement from the parties through sharing the transfer of knowledge. From this decision, Mural Art design was carried out.

\section{c. Production Stages}

The agreed Mural Art idea was immediately executed. The Mural Art design is done on the Computer after the Mural Art sketch is agreed. Due to the fact that there were no walls to paint at the location of the shop, an agreement was made to use digital printing techniques, taking into account the print media which could withstand the sun's rays and the humidity of the seaside waters containing salt. This digital print execution option is considered appropriate because it can shorten the limited time, but community participants still get design knowledge of the process of creating mural art.
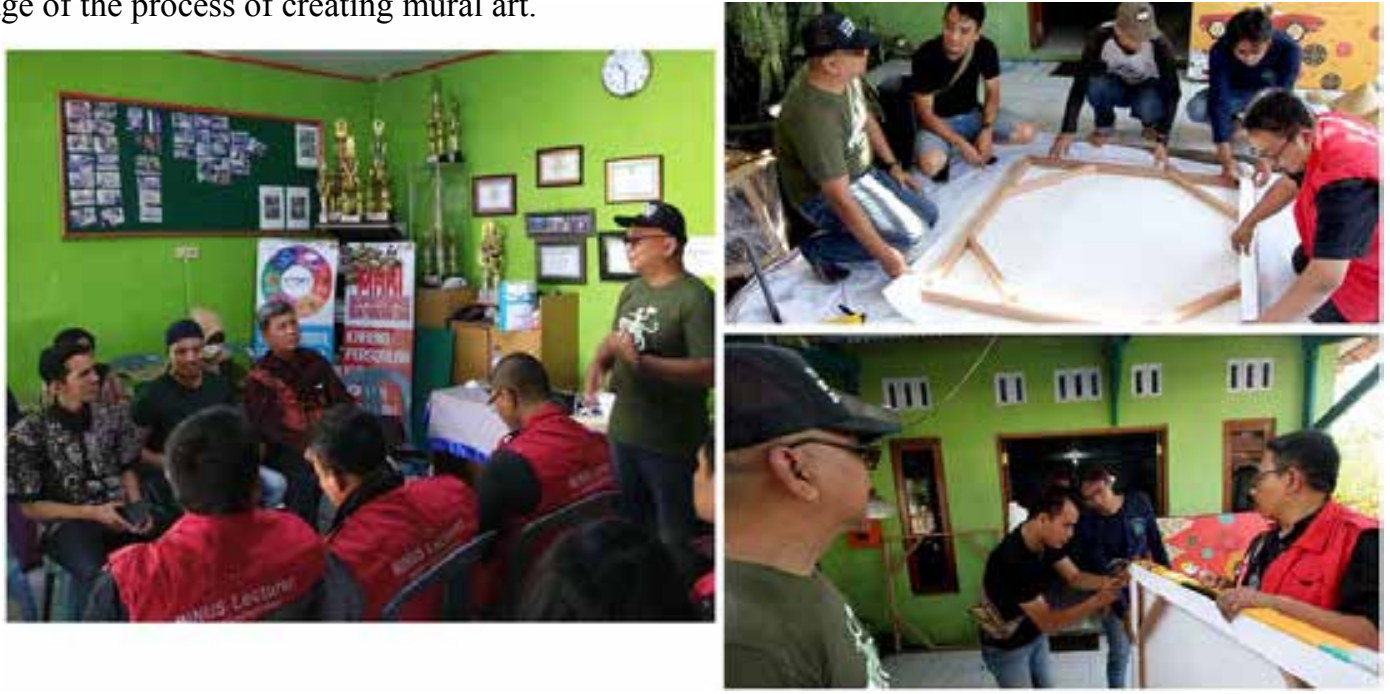

Figure 4. Mural Art Team - CDA Binus held a discussion \& execution of the creation of Mural Art with the community

\section{d. Installment}

(Source: CDA Binus Team)

The installation requires special preparation, because the murals in addition to functioning as an aesthetic element and creating an ambient mood, it turns out that the mural medium also functions as a sun shade and divides the area inside and outside the store. A strong mural holder is needed in the form of welding iron and mural art directly in the drill key below and above the iron. After everything is installed, the mural art still needs a cover to avoid damage from rain water and the sun's rays that wear off the ink.
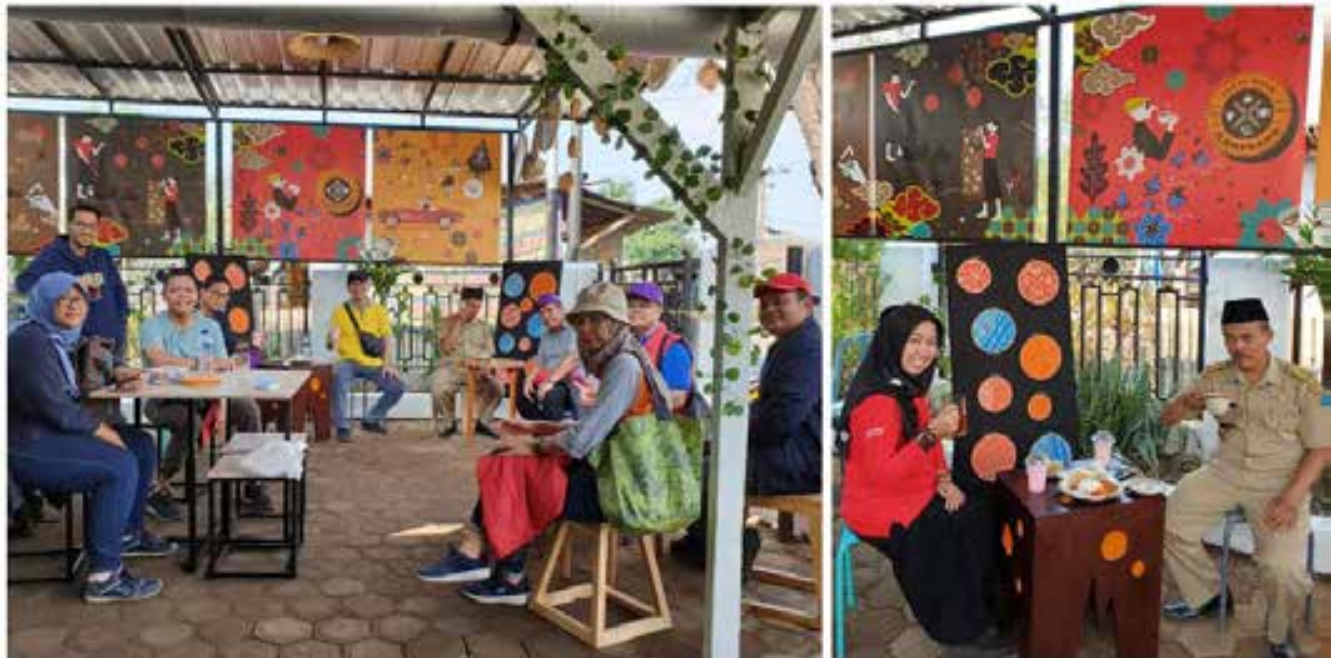

Figure 5. The atmosphere of Kedai Omah Jlamprang - Krapyak Pekalongan with visitors And Koord. CDA Binus Retno Dewanti and Krapyak Village Chief Edi Yulistiyanto, Pekalongan (Source: CDA Binus Team)

Once the Mural Art installation is complete, immediately the atmosphere of the Omamp Jlamprang shop as a cafe is built, all areas are united by the mural image. The atmosphere woke up comfortable and fused. Kedai 
Omah Jlamprang is located on J1. Rasamala Raya N0. 4 Kelurahan Krapyak, Pekalongan (in front Rusunawa Slamaran, Krapyak).

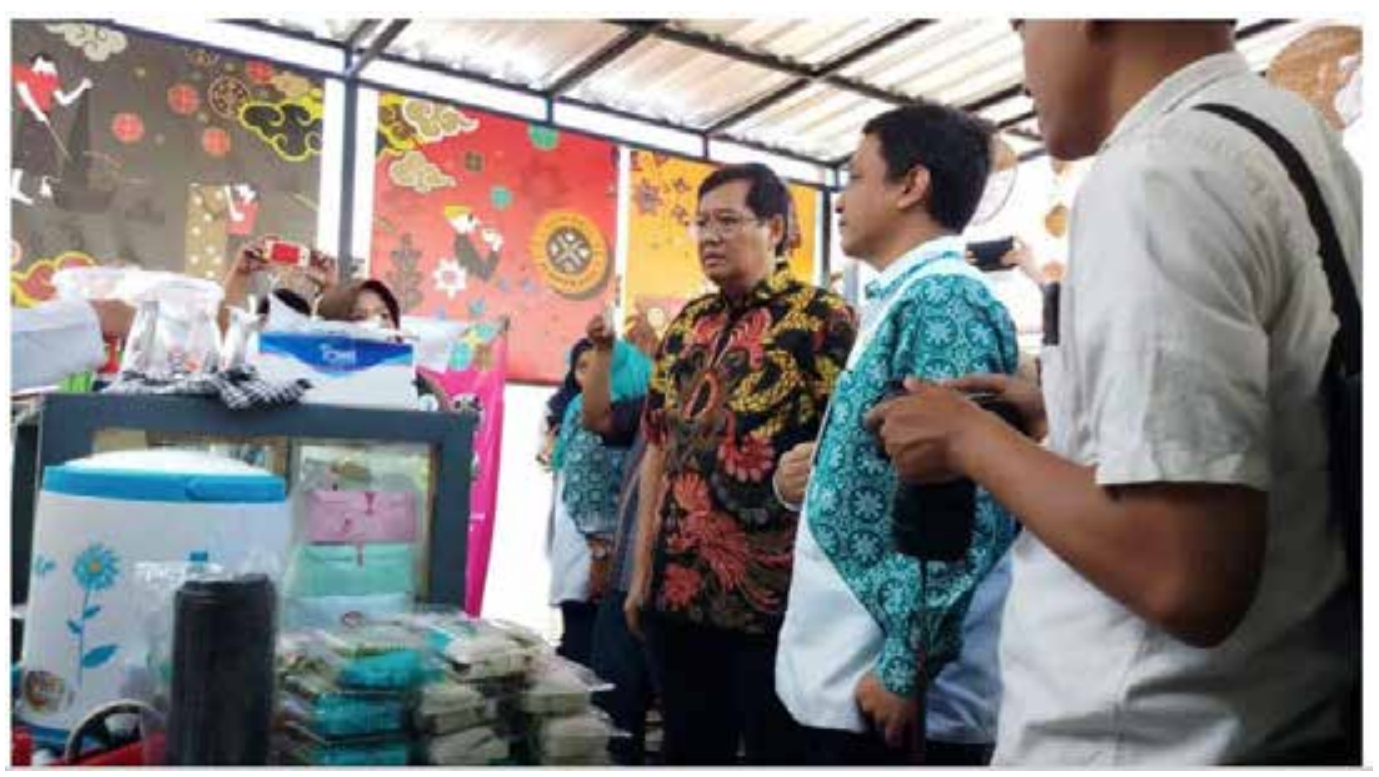

Figure 6. Pekalongan deputy mayor H. Achmad Afzan Arslan Djunaidi and Rector of Binus University Prof. Dr. Ir. Harjanto Prabowo M.M. inaugurated the operation of Kedai Omah Jlamprang - Krapyak Pekalongan

(Source: CDA Binus team)

\section{CONCLUSION}

CDA Binus - Art Mural area at Kedai Omah Jlamprang, Pekalongan has been going well. Throughout the process various stakeholders have been involved including; 2 lecturers providing material, kelurahan staff, store managers, and executors are 4 youth cadets.

It should be noted that all plans require flexibility in the field, due to constraints of time and distance limitations, it was decided to mural in digital print format instead of drawing directly on the wall. Technology helps challenge time and process limitations. Everything has been successfully completed, The Mural Art has become a very dominant element that evokes an artsy mood and conveys the identity narrative of the Krapyak village, which is rich in Jlamprang batik traditions while building a cozy cafe atmosphere

\section{REFERENCE}

Jonathan Baldwin/ Lucienne Roberts, (2006) Visual Communication from Theory to Practice, AVA publishing, UK

Kiriakos Iosifidis, (2009) Mural Art 2: Murals on Huge Public Surfaces Around the World from Graffiti to Trompe L'oeil, Publikat (November 30, 2009)

http://www.imural.id/blog/Pengertian Mural, Sejarah, Perkembangan Dan Perbedaan Mural Dengan Seni Lukis Lainnya

http://batikdan.blogspot.com/2011/09/pola-batik-buketan.html

https://www.cintapekalongan.com/sejarah-batik-pekalongan/

https://kebudayaan.kemdikbud.go.id/ditwdb/batik-pagi-sore-pekalongan/ 